\title{
PEMBERIAN POC GAMAL TERHADAP PERTUMBUHAN DAN PRODUKSI PADI SAWAH (Oryza sativa L.) DENGAN METODE SALIBU
}

\section{APLICATION OF GLIRICIDIA LIQUID ORGANIC FERTILIZER ON GROWTH AND PRODUCTION OF LOWLAND RICE IN SALIBU METHOD}

\author{
Mifta Mamentu $\left.{ }^{1)^{*}}\right)$ Jeanne M. Paulus ${ }^{2)}$ dan Edy Lengkong2) \\ 1) Dinas Pertanian Kabupaten Minahasa Tenggara \\ 2) Dosen Jurusan Budidaya Pertanian Fakultas Pertanian Unsrat \\ *) Korespondensi email : mifta.mamentu@gmail.com
}

\begin{abstract}
The purpose of the research was to studied the application of gliricidia MOL on the growth and yield of lowland rice in the salibu method, and to get the best concentration of gliricidia liquid organic fertilizer (POC) on the growth and production of lowland rice. Field research has been conducted in Tababo Village, Subdistrict of Belang, district of Southeast Minahasa. The treatment in the experiment consists of one treatment factor, that were concentrations of gliricidia POC, ie : 0, 50, 100, 150, and $200 \mathrm{ml} /$ /itre. The results showed that gliricidia POC have an effect on plant height, the number of grain/panicle, and the dry grain yield (GKP) / plot, but not affect the number of productive tillers and weight of 1,000 grain. The best results were achieved in gliricidia POC concentration $200 \mathrm{~m} / /$ itre with the highest values were: plant height was $98.93 \mathrm{~cm} ; 116.420$ grain/panicle; and $8.300 \mathrm{~kg}$ dry grain yield or equivalent to 6.92 ton/ha.
\end{abstract}

Keywords : gliricidia POC, production, lowland rice, salibu method

\section{ABSTRAK}

Penelitian ini bertujuan untuk : (1) mengkaji aplikasi POC gamal pada pertumbuhan dan hasil padi sawah metode salibu, (2) mendapatkan konsentrasi POC gamal yang terbaik pada pertumbuhan dan produksi padi sawah metode salibu. Penelitian lapangan telah dilaksanakan di desa Tababo, Kecamatan Belang, Kabupaten Minahasa Tenggara. Perlakuan dalam percobaan terdiri atas satu faktor perlakuan, yaitu konsentrasi POC gamal : 0, 50, 100, 150, dan $200 \mathrm{ml} \mathrm{POC/liter} \mathrm{air.} \mathrm{Hasil} \mathrm{penelitian}$ menunjukkan bahwa pemberian POC gamal berpengaruh terhadap tinggi tanaman, jumlah gabah/malai, dan hasil gabah kering panen (GKP)/petak, namun tidak berpengaruh terhadap jumlah anakan produktif dan bobot 1000 butir gabah. Konsentrasi POC gamal terbaik dicapai oleh perlakuan pemberian POC gamal pada konsentrasi $200 \mathrm{ml} \mathrm{POC} \mathrm{gamal/} \mathrm{I} \mathrm{air} \mathrm{dengan} \mathrm{nilai-nilai} \mathrm{tertinggi} \mathrm{adalah} \mathrm{:}$ tinggi tanaman $98,93 \mathrm{~cm} ; 116,420$ gabah bernas/malai ; dan 8,300 kg GKP/petak atau setara dengan 6,92 ton/ha.

Kata kunci : POC gamal, produksi, padi sawah, salibu method 


\section{PENDAHULUAN}

Padi (Oryza Sativa L.) merupakan komoditas utama dalam sistem ketahanan pangan nasional. Kebutuhan beras akan terus meningkat seiring dengan laju pertumbuhan penduduk. Berdasarkan realisasi produksi padi dalam 5 tahun terakhir, terindikasi bahwa laju pertumbuhan produksi padi makin menurun dan biaya produksi per satuan luas lahan makin meningkat. Oleh karena itu pencapaian target produksi padi ke depan akan semakin sulit. Upaya pemerintah untuk mewujudkan peningkatan produksi padi pada tahun 2015 dicanangkan Gerakan Penerapan Pengelolaan Tanaman Terpadu (GP-PTT) dan Upaya Khusus (Upsus) lainnya.

Budidaya padi salibu adalah salah satu inovasi teknologi untuk memacu produktivitas/ peningkatan produksi, dan memacu peningkatan produksi padi dengan meningkatkan IP (indeks panen). Teknologi salibu merupakan teknologi budidaya padi yang spesifik lokasi berbasis kearifan lokal.

Budidaya padi salibu merupakan varian teknologi budidaya ratun, yaitu tunggul setelah panen tanaman utama yang tingginya sekitar $25 \mathrm{~cm}$, dipelihara selama 7-10 hari atau dibiarkan hingga keluar tunas baru. Apabila tunas yang keluar kurang dari $70 \%$ maka tidak disarankan untuk dilakukan budidaya salibu. Jika tunas yang tumbuh $>70 \%$ maka potong kembali secara seragam hingga ketinggian $3-5 \mathrm{~cm}$, kemudian dipelihara dengan baik hingga panen. Beberapa keuntungan yang dapat diperoleh dari penerapan budidaya padi salibu adalah: hemat tenaga kerja, waktu, dan biaya, karena tidak dilakukan pengolahan tanah dan penanaman ulang, selain itu menekan kebiasaan petani membakar jerami setelah panen (Erdiman, 2013). Budidaya padi salibu dapat meningkatkan produktivitas padi per unit area dan per unit waktu, dan meningkatkan indeks panen dari sekali menjadi dua sampai tiga kali panen setahun. Jika dibandingkan dengan teknologi ratun konvensional, salibu mampu menghasilkan jumlah anakan yang lebih banyak dan seragam, dan produktivitas bisa sama bahkan lebih tinggi dari tanaman utamanya. Penerapan budidaya padi salibu dengan me- manfaatkan varietas berdaya hasil tinggi, tentu akan lebih menggairahkan aktivitas usahatani, karena dapat diperoleh tambahan hasil yang sangat nyata (Erdiman, dkk., 2014). Melihat keberhasilan pe-ngembangan budidaya padi salibu di beberapa daerah maka perlu upaya untuk mengembangkan budidaya padi salibu di Sulawesi Utara.

Dalam meningkatkan produktivitas padi sawah, selama ini petani sangat menitikberatkan pada penggunaan pupuk kimia. Pupuk merupakan salah satu sarana produksi yang sangat berperan untuk meningkatkan produktivitas tanaman padi. Penggunaan pupuk kimia dapat meningkatkan produktivitas padi sawah tetapi dapat berdampak negatif bagi lingkungan apabila digunakan secara terus menerus. Untuk mengurangi dampak negatif dalam penggunaan pupuk anorganik tersebut perlu diimbangi dengan pemberian pupuk organik.

Salah satu jenis pupuk organik yang dapat digunakan adalah pupuk organik cair (POC). Pupuk organik cair merupakan pupuk organik dalam sediaan cair yang bermanfaat untuk membantu menyediakan ketersediaan unsur hara bagi tanaman dan memperbaiki sifat fisik, biologi dan kimia tanah, karena mengandung mikroorganisme yang dapat membantu penyerapan hara, perangsang pertumbuhan, agen pengendali hama penyakit tanaman dan berpotensi sebagai dekomposer bahan organik yang akan memperbaiki struktur tanah.

Melihat permasalahan di atas, dibutuhkan usaha maksimal untuk menggali dan memanfaatkan potensi bahan organik yang tersedia secara alami diantaranya dapat berupa pemanfaatan tanaman leguminoceae sebagai bentuk organik yang siap dan mampu berperan sebagai suplayer hara secara cepat dan tepat disamping perbaikan fisik dan biologi tanah (Jusuf, 2006). Pupuk organik dapat berbentuk padat maupun cair. Kelebihan pupuk organik cair adalah unsur hara yang dikandungnya lebih cepat tersedia dan mudah diserap akar tanaman. Selain dengan cara disiramkan pupuk cair dapat digunakan langsung dengan cara disemprotkan pada daun atau batang tanaman (Pardosi, dkk., 2014).

Salah satu tanaman yang termasuk golongan leguminoceae dan berpotensi sebagai pupuk organik cair yang dapat memacu pertumbuh- 
an tanaman adalah gamal (Gliricidia sp.). Menurut Ibrahim (2002), bahwa dari daun gamal dapat diperoleh sebesar $3,15 \% \mathrm{~N}, 0,22 \% \mathrm{P}, 2,65 \% \mathrm{~K}$, $1,35 \% \mathrm{Ca}$, dan $0,41 \% \mathrm{Mg}$. Dalam 1 ha tanah, biomassa gamal yang dibudidayakan secara alley cropping dengan jagung mampu menyumbang hara sebanyak $150 \mathrm{~kg} \mathrm{~N}^{-1}, 52 \mathrm{~kg} \mathrm{P} \mathrm{ha-1}^{-1}, 150 \mathrm{~kg} \mathrm{~K}$ $\mathrm{ha}^{-1}, 223 \mathrm{~kg} \mathrm{Ca} \mathrm{ha}^{-1}$, dan $33 \mathrm{~kg} \mathrm{Mg} \mathrm{ha}^{-1}$ per tahun. Selain itu juga, gamal memiliki keunggulan dibandingkan jenis leguminoceae lain yaitu dapat dengan mudah dibudidayakan, pertumbuhannya cepat, produksi biomassanya tinggi. Gamal juga mempunyai kandungan nitrogen yang cukup tinggi dengan $\mathrm{C} / \mathrm{N}$ rendah, menyebabkan biomasa tanaman ini mudah mengalami dekomposisi (Jusuf, dkk., 2007).

Berdasarkan latar belakang dapat diidentifikasi beberapa masalah, yaitu : (1) bagaimana pengaruh pupuk organik cair (POC) gamal terhadap pertumbuhan dan produksi padi sawah metode salibu, (2) apakah terdapat konsentrasi POC terbaik terhadap pertumbuhan dan produksi padi sawah metode salibu.

Penelitian ini bertujuan untuk : (1) mengkaji pengaruh pupuk organik cair (POC) daun gamal terhadap pertumbuhan dan produksi padi sawah metode salibu, (2) mendapatkan konsentrasi pupuk organik cair (POC) gamal terbaik terhadap pertumbuhan dan produksi padi sawah metode salibu. Diharapkan penelitian ini bermanfaat untuk memberikan rekomendasi kepada petani tentang teknologi budidaya padi salibu dan konsentrasi terbaik POC gamal untuk meningkatkan produksi padi sawah metode salibu.

\section{METODE PENELITIAN}

Penelitian dilaksanakan di Desa Tababo, Kecamatan Belang, Kabupaten Minahasa Tenggara mulai dari bulan Desember 2017 sampai dengan Pebruari 2018.

Bahan dan alat yang digunakan adalah ; benih padi varietas Ciherang, pupuk anorganik (Urea, SP36, dan KCL), pupuk organik cair (POC) dari daun gamal (daun gamal, gula merah, larutan EM4, air kelapa, air beras). Alat yang digunakan adalah cangkul, tali, selang, ember, parang, jerigen, handsprayer, sabit, timbangan, gelas ukur, kamera, dan alat tulis menulis.

\section{Metode Penelitian}

Penelitian disusun dalam Rancangan Acak Kelompok (RAK) dengan 3 (tiga) ulangan dan 5 perlakuan konsentrasi POC gamal, yaitu : $\mathrm{P}_{0}=$ Tanpa perlakuan, $\mathrm{P}_{1}=50 \mathrm{ml} P O C$ gamal/liter air, $P_{2}=100 \mathrm{ml} \mathrm{POC}$ gamal/liter air, $P_{3}=150 \mathrm{ml} \mathrm{POC}$ gamal/liter air, dan, $P_{4}=200 \mathrm{ml} P O C$ gamal/liter air

\section{Variabel Pengamatan}

Variabel yang di amati, meliputi : (1) tinggi tanaman, diukur pada saat panen mulai dari pangkal batang sampai daun/malai tertinggi; (2) jumlah anakan produktif, diukur pada saat panen ; (3) jumlah gabah /malai, diukur pada saat panen dengan menghitung seluruh gabah dalam 1 malai ; (4) bobot 1000 butir gabah kering, diukur setelah panen; 8(5) hasil gabah kering panen/petak (GKP), diukur pada saat panen.

\section{Pelaksanaan Percobaan}

Pembuatan pupuk organic cair (POC) gamal : $P O C$ daun gamal dipisahkan dari tangkai kemudian di timbang sebanyak $30 \mathrm{~kg}$ lalu dimasukkan dalam ember yang berukuran 70 liter. Lalu ditambahkan 40 liter air beras di aduk kemudian diperas dan dipisahkan dari ampas. Setelah itu dimasukkan $2 \mathrm{~kg}$ gula merah dan EM4 sebanyak 1 liter dan air kelapa 3 liter. Setelah diaduk secara merata ember di tutup lalu dieratkan dengan menggunakan lakban dan ujung selang dimasukkan kedalam botol yang berisi air dengan tujuan udara yang ada dalam ember dapat keluar tapi udara dari luar tidak dapat masuk proses fermentasi dilakukan selama 15 hari. Ampas dan cairan di pisahkan dengan cara disaring.

Metode Salibu (Balitbangtan, 2015) : Lahan dibersihkan dari jerami sisa panen dan gulma, setelah padi dipanen lahan digenangi air setinggi $\pm 5 \mathrm{~cm}$ selama 2-5 hari, dengan tujuan untuk menjaga kelembapan tanah dan menghindari agar batang padi yang masih berdiri tidak mati kekeringan dan untuk menekan agar tidak tumbuh anakan baru sebelum dilakukan pemangkasan, agar tanaman padi tumbuh serempak. 
Pemotongan batang padi dilakukan saat 7 hari setelah padi dipanen, menggunakan mesin potong rumput dengan ketinggian $\pm 2-3 \mathrm{~cm}$ dari permukaan tanah, jerami bekas pemotongan batang disebarkan pada permukaan lahan. Setelah tunas salibu keluar lakukan pengairan setinggi $2-5$ $\mathrm{cm}$ dari permukaan tanah.

Penyulaman dilakukan saat padi berumur 10 hari setelah pemangkasan dengan memanfaatkan tunas-tunas salibu yang ada, caranya dengan memecah (membagi dua) tunas yang tumbuh hingga perakarannya, kemudian dipecah antara 2-3 anakan, lalu disulamkan ke lokasi tanaman yang tidak tumbuh.

Pemupukan dilakukan dengan cara dibenamkan pada kondisi air macak-macak, pemupukan pertama diberikan sebanyak $100 \mathrm{~kg}$ Urea/ha, $75 \mathrm{~kg} \mathrm{KCl} / \mathrm{ha}$ dan $100 \mathrm{~kg} \mathrm{SP36/ha} \mathrm{pada}$ saat tanaman salibu berumur antara 11 HSP (hari setelah pemotongan) atau satu hari setelah penyulaman. Pemupukan kedua diberikan sebanyak $100 \mathrm{~kg} / \mathrm{ha}$ Urea pada saat tanaman berumur 30 HSP. Kemudian ditambah dengan penyemprotan POC gamal (sesuai dengan konsentrasi pada perlakuan), mulai dari $10 \mathrm{HSP}$ setiap 7 hari dengan frekuensi 6 kali atau sampai pada awal pengisian malai.

Lokasi penelitian sudah endemik dengan hama kepinding tanah maka satu hari setelah pemangkasan langsung dilakukan penyemprotan pestisida. pengendalian hama dan penyakit juga dilakukan dengan cara pengendalian OPT yang didasarkan pada ekologi, efisiensi, ekonomi dalam rangka pengelolaan agroekosistem yang berwawasan lingkungan berkelanjutan.

Pengendalian gulma dilakukan dengan menggunakan cangkul kecil, 2 kali pengendalian atau menyesuaikan dengan kondisi gulma pada pertanaman.

Panen padi salibu dilakukan saat warna gabah menguning (95\%) dan batang masih hijau untuk vaietas ciherang ini padi salibu di panen saat berumur 75 hari, dengan menggunakan sabit.

\section{HASIL DAN PEMBAHASAN}

\section{Pertumbuhan dan Hasil Tanaman Padi Sawah}

Hasil analisis statistik menunjukkan bahwa pemberian pupuk organik cair (POC) gamal berpengaruh terhadap tinggi tanaman, jumlah/malai, dan hasil gabah kering panen (GKP)/petak, namun tidak berpengaruh terhadap jumlah anakan produktif dan bobot 1000 butir (Tabel 1).

\section{Tinggi Tanaman}

Hasil analisis sidik ragam menunjukkan bahwa pemberian POC gamal berpengaruh terhadap tinggi tanaman padi (Tabel 1). Nilai-nilai tinggi tanaman bervariasi antar perlakuan, nilai tertinggi dicapai oleh perlakuan $200 \mathrm{ml}$ POC $\left(\mathrm{P}_{4}\right)$, diikuti oleh perlakuan $50 \mathrm{ml} P O C\left(P_{1}\right)$, perlakuan $100 \mathrm{ml}$ POC $\left(\mathrm{P}_{2}\right)$, dan perlakuan $0 \mathrm{ml}$ POC $\left(\mathrm{P}_{0}\right)$. Tinggi tanaman terendah pada perlakuan $150 \mathrm{ml}$ POC $\left(P_{3}\right)$, walaupun tidak berbeda dengan perlakuan $0 \mathrm{ml} \mathrm{POC,} 50 \mathrm{ml} \mathrm{POC}$ dan $100 \mathrm{ml} \mathrm{POC}$.

Tabel 1. Pengaruh Pemberian POC Gamal Terhadap Pertumbuhan dan Produksi Padi Sawah var. Ciherang dengan Metode Salibu

(Table 1. Influence of Gliricidia POC on Growth and Production of Lowland Rice in Salibu Method)

\begin{tabular}{cccccc}
\hline Perlakuan & $\begin{array}{c}\text { Tinggi tanaman } \\
(\mathrm{cm})\end{array}$ & $\begin{array}{c}\text { Jumlah anakan } \\
\text { produktif }\end{array}$ & $\begin{array}{c}\text { Jumlah } \\
\text { gabah/malai }\end{array}$ & $\begin{array}{c}\text { Bobot } 1000 \\
\text { butir }(\mathrm{g})\end{array}$ & $\begin{array}{c}\text { Hasil gabah } \\
\text { kering } \\
\text { panen/petak }(\mathrm{kg})\end{array}$ \\
\hline 0 ml POC $\left(\mathrm{P}_{0}\right)$ & $97,097 \mathrm{ab}$ & 18,700 & $99,290 \mathrm{~b}$ & 27,123 & $7,400 \mathrm{~b}$ \\
$50 \mathrm{ml} \mathrm{POC}\left(\mathrm{P}_{1}\right)$ & $98,233 \mathrm{ab}$ & 19,433 & $104,400 \mathrm{ab}$ & 26,600 & $7,267 \mathrm{~b}$ \\
$100 \mathrm{ml} \mathrm{POC}\left(\mathrm{P}_{2}\right)$ & $97,467 \mathrm{ab}$ & 19,700 & $111,067 \mathrm{ab}$ & 27,123 & $7,800 \mathrm{ab}$ \\
$150 \mathrm{ml}$ POC $\left(\mathrm{P}_{3}\right)$ & $95,417 \mathrm{~b}$ & 20,867 & $111,093 \mathrm{ab}$ & 27,090 & $8,183 \mathrm{a}$ \\
$200 \mathrm{ml} \mathrm{POC}\left(\mathrm{P}_{4}\right)$ & $98,933 \mathrm{a}$ & 21,200 & $116,420 \mathrm{a}$ & 26,623 & $8,300 \mathrm{a}$ \\
\hline BNT 5\% & 3,035 & - & 14,763 & - & 0,752 \\
\hline
\end{tabular}

Ket : Angka-angka yang diikuti oleh huruf yang sama tidak berbeda nyata pada taraf uji BNT 5\%. 
Oviyanti, dkk. (2016) dalam hasil penelitiannya melaporkan, bahwa penambahan POC daun gamal pada tanaman sawi menyebabkan peningkatan tinggi tanaman, hal ini disebabkan karena pupuk tersebut mengandung unsur hara $\mathrm{N}$, P, K. Demikian juga penelitian Novriani (2016), bahwa pemberian pupuk organik cair daun gamal pada tanaman kubis bunga berpengaruh nyata terhadap peubah tinggi tanaman, jumlah akar, umur berbunga, berat basah tanaman, berat basah bunga dan diameter bunga namun berpengaruh tidak nyata pada peubah jumlah daun, berat kering tajuk dan berat kering, dan perlakuan konsentrasi $45 \mathrm{ml} \mathrm{POC}$ gamal/liter air merupakan perlakuan terbaik dalam meningkatkan pertumbuhan dan produksi tanaman kubis bunga.

\section{Jumlah Anakan Produktif}

Hasil analisis sidik ragam menunjukkan bahwa pemberian POC gamal tidak berpengaruh terhadap jumlah anakan produktif tanaman padi (Tabel 1). Namun demikian nilai jumlah anakan produktif tertinggi pada perlakuan $200 \mathrm{ml} \mathrm{POC}\left(\mathrm{P}_{4}\right)$ anakan dan terendah pada perlakuan $0 \mathrm{ml} P O C$ $\left(P_{0}\right)$ atau kontrol. Hal yang sama dilaporkan oleh Yasin (2016) bahwa perlakuan konsentrasi POC daun gamal tidak berpengaruh nyata terhadap tinggi tanaman dan jumlah anakan tanaman padi sawah. Hal ini dapat disimpulkan bahwa tinggi dan jumlah anakan pada tanaman juga tergantung pada faktor lingkungan seperti temperatur, suhu, panjang hari, dan ketinggian tempat. Selain itu juga tinggi tananam dan jumlah anakan juga bergantung pada varietas tanamannya.

\section{Jumlah Gabah/Malai}

Hasil analisis sidik ragam menunjukkan bahwa pemberian POC gamal berpengaruh terhadap jumlah gabah/malai (Tabel 1). Jumlah gabah/malai tertinggi dicapai oleh perlakuan $200 \mathrm{ml}$ POC $\left(P_{4}\right)$, kemudian diikuti oleh perlakuan $150 \mathrm{ml}$ POC $\left(P_{3}\right)$, perlakuan $100 \mathrm{ml}$ POC $\left(P_{2}\right)$, dan perlakuan $50 \mathrm{ml} \mathrm{POC}\left(P_{1}\right)$. Jumlah gabah/malai terendah pada perlakuan $0 \mathrm{ml} \mathrm{POC}\left(\mathrm{P}_{0}\right)$, walaupun tidak berbeda dengan perlakuan $P_{1}, P_{2}$, dan $P_{3}$.

Pupuk organik cair dari daun gamal memberikan pengaruh pada komponen pertumbuh- an tanaman padi seperti panjang malai dan jumlah gabah per malai, sebagaimana dilaporkan oleh Habibullah, dkk. (2015) dalam hasil penelitiannya, bahwa perlakuan $0.69 \mathrm{~N}, 0.36 \mathrm{P}_{2} \mathrm{O}_{5}, 0.45 \mathrm{~K}_{2} \mathrm{O}$ g/polybag dengan POC $700 \mathrm{ml} /$ polybag dan $0.69 \mathrm{~N}$, $0.36 \mathrm{P}_{2} \mathrm{O}_{5}, 0.45 \mathrm{~K}_{2} \mathrm{O}$ g/polybag dan POC 350 $\mathrm{ml} /$ polybag menghasilkan panjang malai dan jumlah gabah per malai terbaik. Nurman (2002) menyatakan bahwa, unsur hara $\mathrm{N}$ membuat malai lebih panjang dan jumlah butiran gabah lebih banyak, tidak terpenuhinya kebutuhan $\mathrm{N}$ akan menyebabkan jumlah dan kualitas bulir menurun. Menurut Hakim (1986) rendahnya ketersediaan hara pada fase reproduktif menyebabkan terhambatnya beberapa proses metabolisme tanaman yang berdampak pada penurunan hasil tanaman, kekurangan $\mathrm{P}$ dapat mengakibatkan perkembangan akar terhambat, terhambatnya pembentukan bunga, dan penurunan jumlah bij. Demikian halnya dilaporkan oleh Yasin (2016) dalam hasil penelitiannya menunjukkan bahwa, perlakuan konsentrasi POC daun gamal $10 \mathrm{ml} / \mathrm{l}$ memberikan nilai berat gabah/rumpun yang paling berat yaitu $41,98 \mathrm{~g}$, berbeda nyata dengan kontrol yaitu 25,52 g. Menurut Syakhril dkk. (2014) unsur $\mathrm{N}$ berpengaruh terhadap panjang malai, jumlah gabah per malai dan jumlah gabah bernas per malai.

\section{Bobot 1000 butir}

Hasil analisis sidik ragam menunjukkan bahwa pemberian $\mathrm{POC}$ gamal tidak berpengaruh terhadap bobot 1000 butir (Tabel 1). Namun demikian nilai tertinggi pada perlakuan $100 \mathrm{ml} \mathrm{POC}\left(\mathrm{P}_{4}\right)$ dan $0 \mathrm{ml} \mathrm{POC}\left(P_{0}\right)$ dan terendah pada perlakuan $50 \mathrm{ml} \mathrm{POC}\left(\mathrm{P}_{1}\right)$.

Hasil yang sama dilaporkan oleh Habibullah, dkk. (2015), kombinasi N, P, K dengan $\mathrm{POC}$, faktor tunggal $\mathrm{N}, \mathrm{P}, \mathrm{K}$ serta faktor tunggal POC tidak berpengaruh terhadap bobot 1000 butir gabah padi. Hal ini disebabkan karena lebih dominannya pengaruh faktor genetik untuk ukuran biji sehingga perbedaan perlakuan tidak mempengaruhi bobot 1000 butir. Mugnisyah dan Setiawan (1990) menyatakan bahwa rata-rata bobot biji cenderung menjadi tetap pada setiap spesies yang ditentukan oleh bentuk dan ukuran. 


\section{Hasil Gabah Kering Panen/Petak}

Hasil analisis sidik ragam menunjukkan bahwa pemberian POC gamal berpengaruh terhadap hasil gabah kering panen/petak (Tabel 1). Hasil gabah kering panen/petak tertinggi dicapai oleh perlakuan $200 \mathrm{ml} \mathrm{POC}\left(\mathrm{P}_{4}\right)$ dan perlakuan 150 $\mathrm{ml}$ POC $\left(\mathrm{P}_{3}\right)$, kemudian diikuti oleh perlakuan 100 $\mathrm{ml}$ POC $\left(\mathrm{P}_{2}\right)$. Hasil GKP terendah pada perlakuan 0 $\mathrm{ml}$ POC $\left(\mathrm{P}_{0}\right)$, walaupun tidak berbeda dengan perlakuan 50 dan $100 \mathrm{ml} \mathrm{POC}$. Hasil yang sama dilaporkan oleh Yasin (2016) dalam hasil penelitiannya bahwa, hasil gabah saat panen dipengaruhi sangat nyata oleh perlakuan POC daun gamal yang diberikan sehingga dapat meningkatkan bobot gabah panen sebesar 41.98 gram dibandingkan dengan perlakuan kontrol. Hasil penelitian Paulus, dkk. (2017) bahwa aplikasi POC daun gamal berpengaruh terhadap hasil tanaman bawang merah var. Lansuna, hasil tertinggi dicapai pada konsentrasi 150 dan $200 \mathrm{ml} \mathrm{POC/} \mathrm{liter} \mathrm{air.}$

Peningkatan hasil tanaman padi pada penelitian ini disebabkan oleh kandungan unsur hara makro $(\mathrm{N}, \mathrm{P}, \mathrm{K})$ dan hara mikro pada $\mathrm{POC}$ gamal, dimana unsur-unsur tersebut dibutuhkan tanaman untuk proses fisiologi dan metabolisme dalam tanaman yang akan memacu pertumbuhan tanaman dan apabila pertumbuhan tanaman optimal dapat meningkatkan hasil yang optimal juga. Kandungan unsur hara makro terutama nitrogen mampu mendorong dan mempercepat pertumbuhan dan hasil tanaman padi. Dikemukan oleh Gardner, dkk. (1991), bahwa unsur nitrogen sangat dibutuhkan tanaman untuk sintesa asam-asam amino dan protein, terutama pada titik-titik tumbuh tanaman sehingga mempercepat proses pertumbuhan tanaman seperti pembelahan sel dan perpanjangan sel sehingga meningkatkan pertumbuhan dan hasil tanaman. Selain nitrogen, phosphor juga sangat berpengaruh terhadap pertumbuhan tanaman. Poerwowidodo (1992), menyatakan bahwa unsur fosfor berperan dalam menyimpan dan memindahkan energi untuk sintesis karbohidrat, protein, dan proses fotosintesis. Senyawa-senyawa hasil fotosintesis disimpan dalam bentuk senyawa organik yang kemudian dibebaskan dalam bentuk ATP untuk pertumbuhan tanaman. Unsur kalium yang terdapat pada POC daun gamal yang berperan penting dalam setiap proses metabolisme tanaman, yaitu dalam sintesis asam amino dan protein dari ion-ion ammonium. Fungsi utama asam amino adalah sebagai bahan dasar pembentukan protein yang selanjutnya akan digunakan untuk pertumbuhan tanaman (fungsi struktural) dan enzim (fungsi metabolisme). Asam amino ini dapat meningkatkan jumlah klorofil dalam tanaman, meningkatkan aktivitas fotosintensis, dan meningkatkan pertumbuhan akar. Asam amino juga dapat mengatur stomata secara optimal dengan mengendalikan transpirasi tanaman dan meningkatkan reduksi karbondioksida yang akan diubah menjadi karbohidrat yaitu berupa hasil gabah (Abidin, 2013; Gardner, dkk., 1991).

\section{KESIMPULAN DAN SARAN}

\section{Kesimpulan}

Berdasarkan hasil penelitian, dapat disimpulkan: (1) Pemberian POC gamal berpengaruh terhadap tinggi tanaman, jumlah gabah/malai, dan hasil gabah kering panen (GKP)/petak, namun tidak berpengaruh terhadap jumlah anakan produktif dan bobot 1000 butir gabah; (2) Konsentrasi POC gamal terbaik dicapai pada konsentrasi 200 $\mathrm{ml}$ POC gamal/ I air dengan nilai-nilai tertinggi, yaitu: tinggi tanaman $98,93 \mathrm{~cm} ; 116,420$ gabah bernas/malai; dan hasil GKP adalah 8,300 kg/petak atau setara dengan 6,92 ton/ha.

\section{Saran}

Berdasarkan pada hasil penelitian, disarankan kepada petani padi sawah untuk : (1) Memanfaatkan pupuk organik cair (POC) dari daun gamal pada konsentrasi $200 \mathrm{ml} \mathrm{POC/l}$ air untuk meningkatkan pertumbuhan dan produksi padi metode salibu; (2) Mengurangi dosis penggunaan pupuk kimia secara bertahap dan menggunakan POC secara kontinu dan berkelanjutan.

\section{DAFTAR PUSTAKA}

Abidin, Z. 2013. Respon Pertumbuhan dan Perkembangan Tanaman Padi (Oryza sativa L) dengan Berbagai Dosis Pupuk Organik Di Kota Palopo. Skripsi. Universitas Cokroaminoto: Palopo. 
Balitbangtan. 2015. Panduan Teknologi Budidaya

Padi Salibu. Badan Penelitian Dan Pengembangan Pertanian, Kementerian Pertanian.

Balitbangtan. 2013. Pedoman Umum PTT Padi Sawah. Balai Penelitian dan Pengembangan Pertanian, Kementerian Pertanian. Jakarta.

Erdiman. 2013. Teknologi Salibu Meningkatkan Produktivitas Lahan dan Pendapatan Petani. Balai Pengkajian Teknologi Pertanian Sumatera Barat.

Erdiman, Nieldalina, Misran, Y. Mala, dan Ekamirnia. 2014. Pengembangan Teknologi Salibu pada Padi Sawah di tiga Agroekosistem Zone (AEZ) di Sumatera Barat. Laporan Hasil Pengkajian Tahun 2014. BPTP Sumatera Barat

Gardner, F.P., R.B. Pearce, dan R.L. Mitchell. 1991. Fisiologi Tanaman Budidaya (Terjemahan). Universitas Indonesia Press. 428 hal.

Habibullah, Idwar, dan Murniati. 2005. Pengaruh Pupuk N, P, K dan Pupuk Organik Cair (POC) Terhadap Pertumbuhan, Hasil dan Efisiensi Produksi Tanaman Padi Gogo (Oryza sativa L.) di Medium Tanah Ultisol. Department of Agrotechnology, Faculty of Agriculture University of Riau, Vol 2 (2).

Hakim, N. Nyakpa, A.M. Lubis, S.G. Nugroho, M.R. Saul, M.H. Diha, G.B. Hong, dan H.H. Bailey. 1986. Dasar-Dasar IImu Tanah. Universitas Lampung.

Ibrahim, B. 2002. Integrasi Jenis Tanaman Pohon Leguminosae Dalam Sistem Budidaya Pangan Lahan Kering dan Pengaruhnya Terhadap Sifat Tanah, Erosi, dan Pro- duktivitas Lahan. Disertasi. Program Pascasarjana Universitas Hasanudin. Makassar.

Jusuf. L. 2016. Potensi Daun Gamal sebagai Bahan Pupuk Organik Cair Melalui Perlakuan Fermentasi. Jurnal Agrisistem Vol. 2 No.1, Juni 2016.

Kementerian Pertanian. 2015. Pedoman Umum Pelaksanaan Upsus PJ. Jakarta

Mugnisyah, W.Q dan A, Setiawan. 1990. Produksi Benih. Bumi Aksara. Jakarta.

Oviyanti, F., Syarifah, H. Nurul, 2016, Pengaruh Pemberian Pupuk Organik Cair Daun Gamal (Gliricidia sepium (jacq.) Kunth ex walp.) Terhadap Pertumbuhan Tanaman Sawi (Brassica juncea L.), Palembang, Vol $2(1)$.

Pardosi, A. H., Irianto, dan Mukhsin. 2014. Respon Tanaman Sawi Terhadap Pupuk Organik Cair Limbah Sayuran Pada Lahan Kering Ultisol Jambi. Prosiding Seminar Nasional Lahan Suboptimal. Palembang 26-27 September 2014

Paulus .J, M, dan J. Najoan. 2017. Aplikasi Pupuk Organik Cair Pada Pertumbuhan Dan Hasil Bawang Merah (Allium ascalonicum L.) var. Lansuna, Dalam Buku Abstrak Seminar Nasional \& Kongres Perhimpunan Hortikultura Indonesia (Perhorti). Bogor.

Purwowidodo. 1992. Metode Selidik Tanah. Usaha Nasional Press. Surabaya

Syakhril, Riyanto dan H. Arsyad. 2014. Pengaruh Pupuk Nitrogen Terhadap Penampilan dan Produktivitas Padi Inpari dan Sidenuk. Agrifor Vol. XIII (1) 